\title{
Effect of Natural Feed Supplement on Methane Mitigation Potential and Performance in Holstein Bull Calves
}

\author{
Tassilo Brand*, Matthias Miller, Deepashree Kand \\ Mootral SA, Rolle, Switzerland \\ Email: *tbrand@mootral.com
}

How to cite this paper: Brand, T., Miller, M. and Kand, D. (2021) Effect of Natural Feed Supplement on Methane Mitigation Potential and Performance in Holstein Bull Calves. Open Journal of Animal Sciences, $11,222-230$.

https://doi.org/10.4236/ojas.2021.112017

Received: January 22, 2021

Accepted: April 17, 2021

Published: April 20, 2021

Copyright () 2021 by author(s) and Scientific Research Publishing Inc. This work is licensed under the Creative Commons Attribution International License (CC BY 4.0).

http://creativecommons.org/licenses/by/4.0/ (c) (i) Open Access

\begin{abstract}
Introduction of solid feeds in the ration of calves has been shown to increase rumen size and stimulate rumen fermentation. With the initiation of bacterial fermentation in the rumen, the intermediary metabolism moves from a glucose-based to a volatile fatty acid-based metabolism, which releases methane. Mootral $^{\mathrm{TM}}$ has been identified as a promising plant-derived feed supplement to reduce methane emission in dairy and beef cattle. Therefore, the present study aimed at quantifying and mitigating the methane emissions in calves until the slaughtering age of 28 weeks. The study consisted of 20 Holstein bull calves at a commercial farm, assigned randomly into 2 groups (control $\mathrm{n}=$ 10 ; treatment $\mathrm{n}=10$ ), for 2 weeks of adaptation and 8 weeks of sample collection. The calves were fed an increasing amount of milk replacer and ad libitum wheat straw. Mootral was fed once a day to the treatment calves. Methane was measured using GreenFeed units where concentrate feed was offered as bait. The calves were weighed at the start and every four weeks during the experiment. The calves in the treatment group had lower methane emissions $(54 \mathrm{~g} / \mathrm{d})$ compared to the control group $(70 \mathrm{~g} / \mathrm{d})$, a reduction of $22.8 \%$. In contrast, carbon dioxide emission and dry matter intake did not differ significantly between the study groups. Moreover, no negative impact on the average daily weight gain and carcass weight was observed in Mootral fed calves. Although the methane emission ( $\mathrm{g} / \mathrm{kg}$ body weight) was lower in treatment than in the control group, the absolute difference between the groups narrowed with increasing age of the calves. The results suggest a need to increase the dose in line with the increased body weight and intake of the calves. In conclusion, Mootral effectively reduced methane in calves. Further trials to determine the optimal dose for calves are warranted, and as well studies to investigate if interventions (such as Mootral) applied at an earlier life cycle stage would have an impact on methane emissions at later stages of cat-
\end{abstract}


tle's life, would be of scientific interest.

\section{Keywords}

Calves, Methane Emission, Mootral, GreenFeed

\section{Introduction}

Newly born calves are pre-ruminants and they gradually emerge as ruminants [1]. The transition phase (from the pre-ruminant to the ruminant phase) occurs between 3 and 8 weeks of age, while the ruminant phase begins at about 6 to 8 weeks of age, and a calf usually has a fully developed rumen at 12 weeks of age [2]. Introduction of solid feeds in the ration of veal calves has been shown to increase rumen size and stimulate rumen fermentation [3]. With the initiation, bacterial fermentation in the rumen and the intermediary metabolism moves away from being glucose-based towards being volatile fatty acid-based [4]. This results in volatile fatty acid synthesis by bacterial fermentation in a fully developed rumen, which in due course starts methane $\left(\mathrm{CH}_{4}\right)$ production.

The $\mathrm{CH}_{4}$ from enteric fermentation in cattle contributes significantly to greenhouse gas emissions, where international conventions aim to reduce these emissions. There are limited strategies for reducing $\mathrm{CH}_{4}$ from enteric fermentation that can be widely applied. Two such strategies with the greatest potential are diet manipulation and the use of feed supplements. For instance, Moraes et al. (2015) investigated the potential of diet manipulation, e.g. in the form of feeding rations with high starch but low fiber content, and concluded that it is possible to reduce enteric $\mathrm{CH}_{4}$ emissions modestly, yet the cost of implementing this strategy could be up to $49 \%$ higher than the current diet formulation [5]. Therefore, feed supplements may be a better alternative to reduce enteric emissions in a cost-effective manner.

Mootral $^{\mathrm{TM}}$ (Mootral SA, Rolle, Switzerland), a feed supplement with its main ingredients, garlic granules high in allicin content, and citrus extracts, has shown a potential to reduce $\mathrm{CH}_{4}$ emissions. Eger et al. (2018) showed that Mootral reduced the percentage of methanogens during in vitro fermentation, which could be linked to a reduction of enteric $\mathrm{CH}_{4}$ release and production rate [6]. In addition, Mootral demonstrated a reduction in enteric $\mathrm{CH}_{4}$ production in lactating cows while increasing milk yield without affecting milk quality in commercial farm conditions [7]. Correspondingly, Mootral has exhibited a reduction in enteric $\mathrm{CH}_{4}$ yield in beef cattle [8]. Based on these findings, Mootral may also have the ability to impact the $\mathrm{CH}_{4}$ emission in young animals, such as calves. Studies with feed supplements such as Mootral [7] [8], 3-nitrooxy propanol [9] [10], and essential oils [11] [12] have so far primarily focused on investigating $\mathrm{CH}_{4}$ emissions, $\mathrm{CH}_{4}$ intensity per unit of nutrient intake, milk yield or weight gain in adult cattle around the world. However, they have devoted little attention to $\mathrm{CH}_{4}$ 
production in the early ruminating phase of calves (starting at 12 or 13 weeks of age). Thus, the objective of the present short-term study was to understand the effect of Mootral on enteric $\mathrm{CH}_{4}$ emissions and performance in Holstein bull calves managed at a similar production level in a commercial farm location.

\section{Materials and Methods}

\subsection{Experimental Design, Animals, and Diet}

The present study was conducted between December 2019 and March 2020 over a period of 70 days at a commercial farm in the Netherlands. The study was a randomized block design with 2 weeks of adaptation and 8 weeks of the experimental phase. Twenty Holstein Friesian bull calves of similar age (18 weeks) and weight (mean \pm standard deviation; $159 \pm 9 \mathrm{~kg}$ ) were selected for this study and were assigned to either the Control group (no feed supplement) or the Mootral group (4 g Mootral per day and head) in a blind test. Both groups of 10 calves were housed in a similar pen and had free access to clean drinking water. Calves were fed the same diet over the entire trial period (Table 1). Milk replacer was offered twice a day and was increased with the age of the calves. Wheat straw and concentrate were offered ad libitum. Calves in the Mootral group were fed the Mootral feed supplement after the feeding of the milk replacer in the morning by mixing it to feed sugar. Mootral supplement consisted in the major part of dried garlic granules (Allium sativum) with an allicin potential of $>1 \%$, extracts of bitter oranges (Citrus aurantium), and a mixture of saturated fatty acids.

\subsection{Sample Collection and Analysis}

The $\mathrm{CH}_{4}$ and carbon dioxide $\left(\mathrm{CO}_{2}\right)$ emissions were measured over the whole experimental phase using the GreenFeed system (GF; C-Lock Inc., Rapid City, $\mathrm{SD}, \mathrm{USA})$. The GF is an automated system that measures gas fluxes $\left(\mathrm{CH}_{4}, \mathrm{CO}_{2}\right)$ of individual animals, with a built-in automatic feeder that uses concentrate as bait. Each experimental group had their own GF unit attached to their pen to separate the measurements of both groups and avoid falsified measurements. Calves were equipped with RFID ear tags so that the GF unit could identify each

Table 1. Formulation of ration.

\begin{tabular}{ccc}
\hline Ingredients, in \% DM & Control & Mootral \\
\hline Concentrate $^{1}$ & 52.34 & 52.30 \\
Milk replacer $^{2}$ & 40.68 & 40.65 \\
Wheat straw & & 6.97 \\
Mootral $^{3}$ & 6.98 & 0.08 \\
\hline
\end{tabular}

${ }^{1}$ Contained $\%$ dry matter basis: $14 \%$ crude protein, $5 \%$ crude lipid, $4.8 \%$ crude ash, $15.2 \%$ neutral detergent fiber; ${ }^{2}$ Contained $\%$ dry matter basis; $14.4 \%$ crude protein, $18 \%$ crude lipid, $7.15 \%$ crude ash, $0.3 \%$ crude fiber; ${ }^{3}$ Contained $\%$ dry matter basis: $3.2 \%$ crude protein, $5.55 \%$ crude ash, $63 \%$ neutral detergent fiber; ${ }^{4}$ Contained $\%$ dry matter basis: $16.7 \%$ crude protein, $16.6 \%$ crude lipid, $2.1 \%$ crude ash, $0.6 \%$ crude fiber, $0.2 \%$ sodium. 
individual animal. The farm's usual concentrate was used as bait, and calves were able to visit the GF at free will. The amount of concentrate offered, and the $\mathrm{CH}_{4}$ and $\mathrm{CO}_{2}$ emissions at every visit were recorded via internet connection. Only measurements that were longer than 2 minutes were considered for further data analysis.

Body weight (BW) of the calves was measured and recorded once a month. The average daily gain $(\mathrm{kg} / \mathrm{d})$ was calculated according to the BW measurements (Final BW minus Start BW divided by days on feed). Solid feed intake of each calf was calculated by adding concentrate, milk replacer and wheat straw intake $(\mathrm{kg} / \mathrm{d})$. Calves were slaughtered on the same day at a slaughter facility in the Netherlands at 28 weeks of age. Carcass weight and quality were measured on-site.

\subsection{Statistical Analysis}

All data were analyzed using the MIXED procedure of SAS (version 9.4, SAS Institute Inc., Cary, NC, USA). The statistical model included treatments as fixed effects with calves and GF unit as random effects. The data of all the studied variables for each calf were averaged across days and were used in the statistical analysis. Means were separated by pairwise t-test (pdiff option of PROC MIXED). Statistical differences were considered significant at $P \leq 0.05$ and a trend at $0.05<P \leq 0.10$. Data in tables are presented as least squares means.

\section{Results}

The calves' body weight was not significantly different between the dietary treatments both at the start and end of the experiment (Table 2). Nevertheless, the body weight showed a tendency for the difference at the start of the experiment $(P=0.05)$, which was not reflected by the end of the experiment $(P=0.72)$. Daily weight gain, carcass weight, carcass conformation, and carcass fat were similar between the dietary treatments $(P \geq 0.44)$.

Table 2. Effect of Mootral on body weight, body weight gain, carcass gain and slaughter results of Holstein bull calves from 20 to 28 weeks of age.

\begin{tabular}{|c|c|c|c|c|}
\hline \multirow{2}{*}{ Variables } & \multicolumn{2}{|c|}{ Treatment } & \multirow{2}{*}{ SEM } & \multirow{2}{*}{$P$-value } \\
\hline & Control & Mootral & & \\
\hline Start body weight (kg) & 163 & 155 & 3.70 & 0.05 \\
\hline Final body weight $(\mathrm{kg})$ & 248 & 245 & 6.92 & 0.72 \\
\hline Average daily gain $(\mathrm{kg} / \mathrm{d})$ & 1.02 & 1.05 & 0.06 & 0.53 \\
\hline Carcass weight (kg) & 152 & 149 & 4.08 & 0.44 \\
\hline Carcass gain & 0.92 & 0.93 & 0.04 & 0.80 \\
\hline Carcass conformation & 11.3 & 11.4 & 0.22 & 0.66 \\
\hline Carcass fat & 2.4 & 2.3 & 0.22 & 0.66 \\
\hline
\end{tabular}


Dry matter intake did not differ between the Control and Mootral calves (Table 3). Nevertheless, the $\mathrm{CH}_{4}$ emission $\mathrm{g} / \mathrm{d}$ and intensity related to solid intake and body weight were significantly lower by $22.8,23.8$, and $32.3 \%$, respectively, in Mootral compared to Control fed calves $(P \leq 0.01)$. In contrast, no difference in $\mathrm{CO}_{2} \mathrm{~g} / \mathrm{d}$ was observed between the groups.

The $\mathrm{CH}_{4}$ emission $\mathrm{g} / \mathrm{kg}$ body weight of the calves was significantly different between Control and Mootral groups at all BW measurement weeks (Figure 1). The absolute differences between the dietary treatments in the measurement weeks were greatest in week 22 and lowest in week 26.

Table 3. Effect of Mootral on intake, and methane and carbon dioxide emissions from 20 to 28 weeks of age.

\begin{tabular}{lcccc}
\hline \multirow{2}{*}{ Variables } & \multicolumn{2}{c}{ Treatment } & SEM & $P$-value \\
\cline { 2 - 3 } & Control & Mootral & & \\
\hline Intake & & & & \\
Solid feed $(\mathrm{kg} / \mathrm{d})$ & 2.84 & 2.93 & 0.14 & 0.55 \\
Total feed ${ }^{1}\left(\mathrm{~g} / \mathrm{kg}^{0.75} / \mathrm{d}\right)$ & 77.1 & 79.3 & 2.73 & 0.43 \\
Methane & & & & \\
g/d & 70 & 54 & 3.90 & $<0.01$ \\
mg/g solid feed intake & 24.8 & 18.9 & 1.47 & $<0.01$ \\
g/kg BW & 0.31 & 0.21 & 0.02 & $<0.01$ \\
g/kg BW gain & 69.6 & 53.3 & 5.85 & 0.01 \\
g/kg carcass gain & 76.9 & 60.0 & 5.85 & 0.01 \\
Carbon dioxide & & & & $<0.01$ \\
g/d & 5081 & 4841 & 176.3 & 0.19 \\
mg/g solid feed intake & 1.80 & 1.68 & 0.067 & 0.09 \\
Methane/Carbon dioxide & 0.014 & 0.011 & 0.0007 & \\
\hline
\end{tabular}

${ }^{1}$ Total feed intake contains milk replacer, concentrate, and wheat straw.

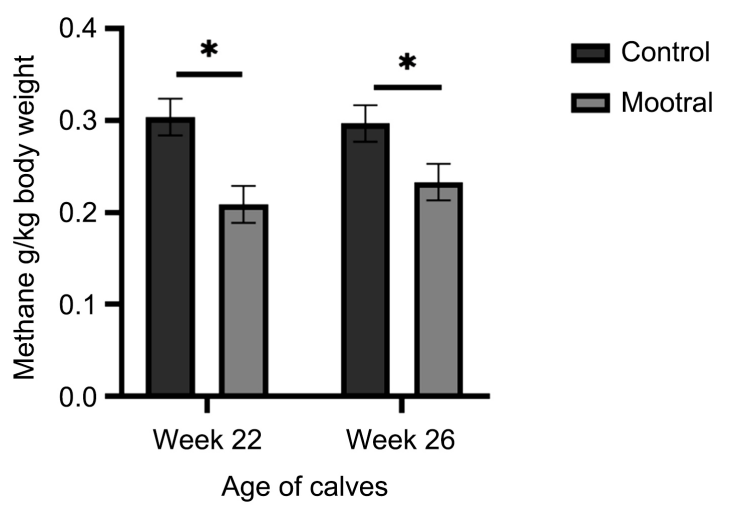

Figure 1. Methane emission $\mathrm{g} / \mathrm{kg}$ body weight at different ages of the calves fed for control $(\mathrm{n}=10)$ and Mootral $(\mathrm{n}=10)$ based diets. 


\section{Discussion}

Dairy and beef production are mainly responsible for the enteric $\mathrm{CH}_{4}$ emission from livestock [13]. The convention of enteric $\mathrm{CH}_{4}$ research had focused on the life stages of ruminants when milk is produced, or weight gain is increased. It must be considered that each dairy cow and beef cattle not only emits $\mathrm{CH}_{4}$ in high-performance phases, but also as soon as the rumen development begins. Studies have confirmed that the same microorganisms present in a mature cattle rumen are already present in very early rumen development stages of calves [14]. Guzman et al. (2015) studied the composition of the rumen microbiome of newborn Holstein calves and found that already 20 minutes after birth methanogens were existing [15]. Another experiment with newborn Holstein calves reported that calves were able to produce $\mathrm{CH}_{4}$ two days after birth [16]. In our study, we showed that veal calves produce and emit a substantial amount of $\mathrm{CH}_{4}$ (on average $70 \mathrm{~g} / \mathrm{d}$ and $54 \mathrm{~g} / \mathrm{d}$ in the Control group and Mootral group respectively) at the age of 20 to 28 weeks. Our findings are in accordance with a study that showed the effect of feeding different amounts of milk replacer to newborn Holstein calves on $\mathrm{CH}_{4}$ emissions using a respiration chamber [17]. The authors observed that the calves produced $\mathrm{CH}_{4}$ at the first measurement after 6 weeks which was doubled after 14 weeks. Similarly for other ruminants, the effect of tea saponins and soybean oil supplementation on the $\mathrm{CH}_{4}$ emissions of lambs also found that young lambs produced substantial amounts of $\mathrm{CH}_{4}(26 \mathrm{~L} / \mathrm{kg} \mathrm{DMI})$ in early parts of their life [18]. With this proof that young ruminants are capable of producing greenhouse gases such as $\mathrm{CH}_{4}$, the need for $\mathrm{CH}_{4}$ mitigation strategies is even more pressing.

The tested Mootral supplement is a blend of dried garlic granules (Allium sativum) with high allicin potential, and citrus extract obtained from bitter oranges (Citrus aurantium). Allicin from garlic is known for its antimicrobial and antiviral activity [19], similar effects were observed for polyphenols present in citrus extracts [20]. Although it is difficult to assign the effects of a plant-based blend to its individual ingredients, studies with Mootral suggested, that the combination of the above-mentioned ingredients had $\mathrm{CH}_{4}$ inhibiting effects in the rumen system. In the present study, the Mootral fed group showed reduced $\mathrm{CH}_{4}$ emissions of about 23\% compared to the Control group. A similar reduction of 23\% in $\mathrm{CH}_{4}$ emissions was observed by Roque et al. (2019) who studied the effect of Mootral in a feedlot trial with crossbred steers to examine possible $\mathrm{CH}_{4}$ reduction, also using the GF system [8]. However, the $\mathrm{CH}_{4}$ emissions per $\mathrm{kg}$ of DMI of the beef steers were lower than those of the calves in the present study, indicating that the production of veal is possibly more emission-intensive than beef production. In lactating dairy cows, Mootral also showed a significant reduction in $\mathrm{CH}_{4}$ emissions of up to $38 \%$ on a commercial farm [7]. Similarly, the effect of Mootral on $\mathrm{CH}_{4}$ reduction by alteration of the rumen microbiome, particularly the archaeal community, was confirmed by using the in vitro RUSITEC technique with rumen fluid from Holstein cows without any negative impact on ru- 
men fermentation [6]. Another in vitro trial using rumen content of 60 days (i.e., 8.5 weeks) old Holstein calves proved that garlic oil was able to reduce the $\mathrm{CH}_{4}$ production significantly [21]. As a result, the present and the above-mentioned studies suggest that Mootral supplementation is an effective strategy to reduce $\mathrm{CH}_{4}$ emissions not only in adults but also in young animals.

Besides reduction in $\mathrm{CH}_{4}$ emissions, no negative impact of Mootral supplementation on the palatability of the feed and the average daily gain in veal calves was observed in the present study. Similar results for Mootral supplementation were reported on the average daily gain of crossbred steers in an experiment over 12 weeks [8]. Nevertheless, research suggested that garlic had the potential to enhance performance in young cattle. In a study where garlic paste was fed to 18 crossbred calves from the age of 5 days until 2 months of age, the calves had significantly higher daily weight gain when compared to the Control group [22]. However, in the present study, the reduced sample size (10 calves per treatment) may have possibly refrained from detecting such influence on the performance data of the calves.

In the present study, $\mathrm{CH}_{4}$ emissions (in $\mathrm{g} / \mathrm{kg} \mathrm{BW}$ ) from the Control group were always greater than in the Mootral group. However, the emissions differences between both groups decreased in the course of the trial (see Figure 1). It may be postulated that as the dosage of the Mootral remained unchanged throughout the experiment $\left(4 \mathrm{~g} / \mathrm{d}\right.$ ), the difference in $\mathrm{CH}_{4}$ emissions (in $\mathrm{g} / \mathrm{kg}$ $\mathrm{BW}$ ) between the studied groups may have decreased. Along the line, other studies have also shown a need for different dosages of $\mathrm{CH}_{4}$ inhibiting supplements depending on use, body weight, and feed intake of ruminants. For instance, 3-nitrooxypropanol at $150 \mathrm{mg} / \mathrm{kg}$ DMI and $200 \mathrm{mg} / \mathrm{kg}$ DMI were most effective against $\mathrm{CH}_{4}$ emissions of dairy cows [10] and beef cattle [23], respectively. Accordingly, it may be indicated that Mootral dosage may need to be selected proportionally to the body weight (growth) of the calves.

\section{Conclusion}

In conclusion, calves fed Mootral have shown a significant reduction in $\mathrm{CH}_{4}$ emission by $22.8 \%$ without being restricted in their performance. Mootral supplementation did not negatively influence the feed intake and carcass characteristics of the veal calves. Smaller differences between the Control and Mootral group on $\mathrm{CH}_{4}$ emissions in $\mathrm{g} / \mathrm{kg} \mathrm{BW}$ over the course of the trial indicated that a dose adjustment according to the growing BW of the calves could have been necessary. Further research is needed to understand the effect of Mootral in a dose-response manner to further investigate the $\mathrm{CH}_{4}$ reduction potential in calves.

\section{Acknowledgements}

The authors greatly acknowledge the support of the commercial farm where the study was conducted and Lynette Chew for critically reviewing the manuscript. 


\section{Conflicts of Interest}

The authors declare no conflicts of interest regarding the publication of this paper.

\section{References}

[1] Kirchgeßner, M., Roth, F.X., Schwarz, F.J. and Stangl, G. (2008) Tierernährung: Leitfaden für Studium, Beratung und Praxis. DLG-Verlag, Frankfurt am Main.

[2] Govil, K., Yadav, D.S., Patil, A.K., Nayak, S., Baghel, R.P.S., Yadav, P.K., Malapure, C.D. and Thakur, D. (2017) Feeding Management for Early Rumen Development in Calves. Journal of Entomology and Zoology Studies, 5, 1132-1139.

[3] Suárez, B.J., Van Reenen, C.G., Stockhofe, N., Dijkstra, J. and Gerrits, W.J.J. (2007) Effect of Roughage Source and Roughage to Concentrate Ratio on Animal Performance and Rumen Development in Veal Calves. Journal of Dairy Science, 90, 2390-2403. https://doi.org/10.3168/jds.2006-524

[4] Leek, B.F. (1993) Digestion in the Ruminant Stomach. In: Swenson M.J. and Reece W.O., Eds., Dukes' Physiology of Domestic Animals, 11th Edition, Cornell University Press, Ithaca, New York, USA.

[5] Moraes, L.E., Fadel, J.G., Castillo, A.R., Casper, D.P., Tricarico, J.M. and Kebreab, E. (2015) Modeling the Trade-Off between Diet Costs and Methane Emissions: A Goal Programming Approach. Journal of Dairy Science, 98, 5557-5571.

https://doi.org/10.3168/jds.2014-9138

[6] Eger, M., Graz, M., Riede, S. and Breves, G. (2018) Application of Mootral ${ }^{\mathrm{TM}}$ Reduces Methane Production by Altering the Archaea Community in the Rumen Simulation Technique. Frontiers in Microbiology, 9, Article 2094.

https://doi.org/10.3389/fmicb.2018.02094

[7] Vrancken, H., Suenkel, M., Hargreaves, P.R., Chew, L. and Towers, E. (2019) Reduction of Enteric Methane Emission in a Commercial Dairy Farm by a Novel Feed Supplement. Open Journal of Animal Sciences, 9, 286-296.

https://doi.org/10.4236/ojas.2019.93024

[8] Roque, B.M., van Lingen, H.J., Vrancken, H. and Kebreab, E. (2019) Effect of Mootral-A Garlic- and Citrus-Extract-Based Feed Additive-On Enteric Methane Emissions in Feedlot Cattle. Translational Animal Science, 3, 1383-1388. https://doi.org/10.1093/tas/txz133

[9] Martinez-Fernandez, G., Duval, S., Kindermann, M., Schirra, H.J., Denman, S.E. and McSweeney, C.S. (2018) 3-NOP vs. Halogenated Compound: Methane Production, Ruminal Fermentation and Microbial Community Response in Forage Fed Cattle. Frontiers in Microbiology, 9, Article No. 1582.

https://doi.org/10.3389/fmicb.2018.01582

[10] Melgar, A., Welter, K.C., Nedelkov, K., Martins, C.M.M.R., Harper, M.T., Oh, J., Räisänen, S.E., Chen, X., et al. (2020) Dose-Response Effect of 3-Nitrooxypropanol on Enteric Methane Emissions in Dairy Cows. Journal of Dairy Science, 103, 6145-6156. https://doi.org/10.3168/jds.2019-17840

[11] Castro-Montoya, J., Peiren, N., Cone, J.W., Zweifel, B., Fievez, V. and De Campeneere, S. (2015) In Vivo and In Vitro Effects of a Blend of Essential Oils on Rumen Methane Mitigation. Livestock Science, 180, 134-142.

https://doi.org/10.1016/j.livsci.2015.08.010

[12] Hart, K.J., Jones, H.G., Waddams, K.E., Worgan, H.J., Zweifel, B. and Newbold, C. (2019) An Essential Oil Blend Decreases Methane Emissions and Increases Milk 
Yield in Dairy Cows. Open Journal of Animal Sciences, 9, 259-267.

https://doi.org/10.4236/ojas.2019.93022

[13] United States Environmental Protection Agency (EPA) (2020) Inventory of U.S. Greenhouse Gas Emissions and Sinks: 1990-2018.

[14] Jami, E., Israel, A., Kotser, A. and Mizrahi, I. (2013) Exploring the Bovine Rumen Bacterial Community from Birth to Adulthood. The ISME Journal, 7, 1069-1079. https://doi.org/10.1038/ismej.2013.2

[15] Guzman, C.E., Bereza-Malcolm, L.T., De Groef, B. and Franks, A.E. (2015) Presence of Selected Methanogens, Fibrolytic Bacteria, and Proteobacteria in the Gastrointestinal Tract of Neonatal Dairy Calves from Birth to 72 Hours. PLoS ONE, 10, e0133048. https://doi.org/10.1371/journal.pone.0133048

[16] Friedman, N., Jami, E. and Mizrahi, I. (2017) Compositional and Functional Dynamics of the Bovine Rumen Methanogenic Community across Different Developmental Stages. Environmental Microbiology, 19, 3365-3373.

https://doi.org/10.1111/1462-2920.13846

[17] Tümmler, L.-M., Derno, M., Röttgen, V., Vernunft, A., Tuchscherer, A., Wolf, P. and Kuhla, B. (2020) Effects of 2 Colostrum and Subsequent Milk Replacer Feeding Intensities on Methane Production, Rumen Development, and Performance in Young Calves. Journal of Dairy Science, 103, 6054-6069. https://doi.org/10.3168/jds.2019-17875

[18] Mao, H.-L., Wang, J.-K., Zhou, Y.-Y. and Liu, J.-X. (2010) Effects of Addition of Tea Saponins and Soybean Oil on Methane Production, Fermentation and Microbial Population in the Rumen of Growing Lambs. Livestock Science, 129, 56-62. https://doi.org/10.1016/j.livsci.2009.12.011

[19] Ankri, S. and Mirelman, D. (1999) Antimicrobial Properties of Allicin from Garlic. Microbes and Infection, 1, 125-129. https://doi.org/10.1016/S1286-4579(99)80003-3

[20] Daglia, M. (2012) Polyphenols as Antimicrobial Agents. Current Opinion in Biotechnology, 23, 174-181. https://doi.org/10.1016/j.copbio.2011.08.007

[21] Hernandez, A., Kholif, A.E., Lugo-Coyote, R., Elghandour, M.M.Y., Cipriano, M., Rodríguez, G.B., Odongo, N.E. and Salem, A.Z.M. (2017) The Effect of Garlic Oil, Xylanase Enzyme and Yeast on Biomethane and Carbon Dioxide Production from 60-D Old Holstein Dairy Calves Fed a High Concentrate Diet. Journal of Cleaner Production, 142, 2384-2392. https://doi.org/10.1016/j.jclepro.2016.11.036

[22] Vyas, D., McGinn, S.M., Duval, S.M., Kindermann, M.K. and Beauchemin, K.A. (2016) Optimal Dose of 3-Nitrooxypropanol for Decreasing Enteric Methane Emissions from Beef Cattle Fed High-Forage and High-Grain Diets. Animal Production Science, 58, 1049-1055. https://doi.org/10.1071/AN15705

[23] Ghosh, S., Mehla, R.K., Sirohi, S.K. and Roy, B. (2010) The Effect of Dietary Garlic Supplementation on Body Weight Gain, Feed Intake, Feed Conversion Efficiency, Faecal Score, Faecal Coliform Count and Feeding Cost in Crossbred Dairy Calves. Tropical Animal Health and Production, 42, 961-968.

https://doi.org/10.1007/s11250-009-9514-5 